\title{
NATURALEZA JURÍDICA DE LAS MULTAS EN LA CONTRATACIÓN ADMINISTRATIVA: ALGUNAS REFLEXIONES SOBRE LA AUTORIDAD ADMINISTRATIVA Y EL PRINCIPIO DE LEGALIDAD
}

\author{
LEGAL NATURE OF FINES IN ADMINISTRATIVE CONTRACTING: \\ SOME REFLECTIONS ON ADMINISTRATIVE AUTHORITY AND THE \\ PRINCIPLE OF LEGALITY
}

\section{Cristóbal Aguilera Medina*}

\begin{abstract}
RESUMEN: El presente trabajo intenta resolver la pregunta sobre la naturaleza jurídica de la multa en la contratación administrativa. La respuesta que se ofrece es que se trata de una sanción administrativa, desechando la tesis según la cual se trataría de una cláusula penal. Los argumentos que se exponen se enmarcan en dos reflexiones. Primero, sobre la naturaleza de la autoridad administrativa y el carácter potestativo de su obrar. Segundo, sobre la potestad de multar y el principio de legalidad. El contexto normativo en el que se desenvuelven las reflexiones es la Ley No 19.886 .
\end{abstract}

Palabras claves: multa, autoridad administrativa, contratación administrativa, principio de legalidad, Ley No 19.886

ABSTRACT: The present article tries to solve the question about the juridical nature of the fine in administrative contracting. The answer offered is that it is an administrative sanction, discarding the thesis according to which it would be a penalty clause. The arguments that are exposed are framed in two reflections. First, about the nature of the administrative authority and the optional nature of their actions. Second, about the power to fine and the principle of legality. The normative context in which the reflections take place is Law No 19.886 .

Keywords: Fine, administrative authority, administrative contracting, principle of legality, Law No 19.886.

\section{INTRODUCCIÓN}

Uno de los asuntos más relevantes en el desarrollo dogmático del derecho administrativo dice relación con la discusión sobre la naturaleza jurídica del contrato administrativo. Esta discusión suele remontarse a la polémica entre Paul Laband, Otto Mayer y Hans Kelsen a fines del siglo XIX que versó sobre la pregunta de si el contrato administrativo es un convenio o una actuación unilateral del Estado que requiere de aceptación ${ }^{1}$.

\footnotetext{
Magíster en Derecho Administrativo. Profesor de Derecho Administrativo, Universidad Finis Terrae. Dirección Postal: Av. Pedro de Valdivia 1509, Providencia, Región Metropolitana, Chile. Correo electrónico: caguilera@uft.cl. Código Orcid 0000-0002-8661-0912. Este trabajo forma parte de la tesis defendida para la obtención del grado de Magíster en Derecho Administrativo en la Universidad de los Andes. Agradezco los comentarios del Tribunal, integrado por los profesores Jaime Arancibia, Claudio Moraga y Juan Carlos Flores.

1 Huergo (1998) pp. 119-197.
} 
La relevancia de esta discusión es absoluta. Entre otros motivos, esto se debe a que está íntimamente relacionada con la discusión sobre la autonomía científica del derecho administrativo $^{2}$. Con todo, a pesar de su importancia, esta discusión no ha tenido un tratamiento debido en estas latitudes. Basta revisar la historia de la Ley No 19.886 para comprobarlo: no hay en ella ninguna alusión a esta crucial controversia. Este escenario, para beneficio de la dogmática administrativista chilena, se ha ido remediando en el último tiempo en el que han aparecido trabajos que buscan instalar esta discusión en nuestro medio ${ }^{3}$.

El presente trabajo se inserta en el contexto de la discusión sobre la naturaleza del contrato administrativo. En este marco, nos centraremos en una cuestión específica, que dice relación con la pregunta sobre la naturaleza jurídica de la multa en la contratación administrativa. La tesis que proponemos es que consiste en una sanción administrativa. Esta tesis se funda y, a la vez, refuerza el argumento de que el contrato administrativo es un acto administrativo mixto y modal ${ }^{4}$. Así, partimos de la base de que la discusión que analizaremos es secundaria respecto de la discusión principal y anterior sobre la naturaleza del contrato administrativo.

La aproximación de este trabajo a la pregunta objeto del mismo es fundamentalmente teórica. Esto significa que nos moveremos en el plano conceptual (dilucidar la naturaleza), sin detenernos en los efectos jurídicos prácticos (por ej. garantías del particular) ${ }^{5}$ o de política pública (por ej. eficacia de la contratación administrativa) ${ }^{6}$ derivados de la tesis que sostenemos. Solo abordaremos un efecto en el plano jurídico-conceptual, que dice relación con el principio de legalidad. En consecuencia, el trabajo se dividirá en dos partes. En una primera parte abordaremos la naturaleza jurídica de las multas en la contratación administrativa a partir de un análisis de la autoridad administrativa y el carácter potestativo de su obrar. En segundo lugar, y sobre la base de lo anterior, analizaremos ciertos aspectos relativos al principio de legalidad, específicamente relacionados con la potestad de multar. En ambas secciones el análisis se enmarcará en la Ley No 19.886, aunque algunas reflexiones no se restringen a este cuerpo legal ${ }^{7}$. Terminaremos resumiendo las conclusiones.

\section{NATURALEZA DE SANCIÓN ADMINISTRATIVA DE LA MULTA EN LA CONTRATACIÓN ADMINISTRATIVA}

Esta primera sección tiene por objeto exponer algunos argumentos que sustentan la tesis de que la multa en la contratación administrativa es una sanción de naturaleza administrativa y no contractual. Los argumentos siguen el siguiente esquema: primero, identifi-

\footnotetext{
2 Loo (2018) pp. 149-154.

3 Recientemente se ha publicado un trabajo del profesor Jaime Arancibia que toma partido en esta discusión: Arancibia (2019). Antes había esbozado esta tesis en Arancibia (2017) pp. 9-11.

4 Arancibia (2019) pp. 31-35.

5 Lara y García-Huidobro (2014) pp. 380-382; Lledó y Pardo (2015) pp. 61-65.

6 Lledó y Pardo (2015) p. 71.

7 Estas reflexiones cobran mayor relevancia para el caso de legislaciones que no confieren de modo expreso la potestad de sancionar con multa el incumplimiento de un contrato administrativo a la autoridad administrativa, y no en aquellas en que sí se confiere esta potestad, por ej. Ley 18.696.
} 
caremos el criterio en virtud del cual es posible resolver la pregunta sobre la naturaleza de la multa. En segundo lugar, ahondaremos en este criterio, que es la singularidad de la autoridad administrativa como parte del contrato administrativo y el carácter potestativo de su obrar. En tercer lugar, analizaremos el concepto de potestad.

\section{UN PROBLEMA DE CRITERIO DE DETERMINACIÓN}

Preguntar por la naturaleza de una cosa es una pregunta que busca identificar "aquello que hace que una cosa sea lo que es" ${ }^{8}$. Cuando a esta pregunta se le asigna el adjetivo jurídico, la cuestión suele volverse difusa. Esto ocurre porque no está del todo claro cuál es la respuesta que busca obtener quien formula una pregunta en estos términos, sobre todo cuando aquello cuya naturaleza se intenta dilucidar es una creación normativa.

En nuestro caso, la pregunta sobre la naturaleza jurídica de las multas en la contratación administrativa parece reducirse a la siguiente disyuntiva: cláusula penal o sanción administrativa9. Por evidente que sea, una primera constatación que debemos advertir es que se trata de una "multa". El Diccionario de la lengua española define la multa como "sanción administrativa o penal que consiste en la obligación de pagar una cantidad determinada de dinero"10. La multa es, pues, primeramente una sanción.

Para quienes sostienen que la multa en la contratación administrativa es sanción administrativa, la definición de la multa como una sanción no reviste ningún inconveniente ${ }^{11}$. Con todo, para quienes plantean que se trata de una cláusula penal, esto no es evidente y merece algunas explicaciones. La cláusula penal tiene diversas funciones, como la de avaluar perjuicios, garantizar el cumplimiento de la obligación principal, entre otras ${ }^{12}$. Sin embargo, parece claro que, si se acepta que la multa es cláusula penal, dicha cláusula tiene la función de sancionar ( aflictiva $^{13}$ ). Dos razones sustentan este punto. En primer lugar, la misma denominación de "multa" que le asignó el legislador. En segundo lugar, el contexto gramatical en el que se encuentra la palabra multa en la Ley No 19.886. Para efectos de lo que nos interesa, la palabra multa se encuentra en el inciso tercero del artículo 11. En esta disposición, la voz multa se sitúa en una oración que hace referencia a las sanciones. Así, es dable concluir que la multa se comprende como una especie del género sanción al cual el inciso alude. A este argumento, que apunta a la literalidad, se puede sumar el marcado énfasis sancionador del artículo 79 ter del Reglamento de la Ley No 19.886 (lo veremos en detalle más adelante). Por lo demás, el sentido original de la cláusula penal es sancionar las infracciones al contrato ${ }^{14}$, el cual coincide con el sentido primero que se sigue de la lectura del artículo 1535 del Código Civil.

\footnotetext{
8 Alvira, Clavell y Melendo (2001) p. 29.

9 Dictamen CGR No 30.003 (2014).

10 Diccionario de la Lengua Española (2001) 22a edición.

11 Para un concepto de la multa como sanción administrativa: Bermúdez (2014) p. 354 y Moraga (2019) 
Habiendo aclarado lo anterior, cabe ahora resolver la cuestión central: si la multa es de carácter contractual o administrativa. Esto nos pone frente a una serie de disyuntivas. En efecto, con la pregunta sobre la naturaleza jurídica de la multa se suele intentar resolver la duda sobre cuál es el título en virtud del cual la Administración actúa, es decir, si aquello en lo que tiene su origen la multa ${ }^{15}$, es un derecho subjetivo o una potestad. Por otro lado, también la cuestión de la naturaleza apunta a resolver la duda de si al cursarla la Administración actúa de un modo potestativo o facultativo. Luego, también nos pone frente al problema de si la fuente última de su acción es una cláusula del contrato administrativo o una norma legal. Finalmente, la pregunta sobre la naturaleza también alude al hecho que motiva la multa: ¿infracción administrativa o incumplimiento contractual?

Es cierto que todos estos ámbitos están relacionados. Con todo, diferenciarlos es fundamental para saber cuál es la respuesta que se busca obtener con la pregunta sobre la naturaleza jurídica de la multa. En efecto, la falta de claridad en lo anterior puede llevar a concluir, por ejemplo, que la multa es de naturaleza contractual porque su fuente es un contrato sin reparar en que el carácter del obrar de toda autoridad pública es potestativo. De igual modo, se puede sostener que el título de la multa es una potestad sancionadora debido a que la multa la impone la Administración, sin advertir el contexto en el que se ejerce, que es el cumplimiento de un contrato ${ }^{16}$.

Frente a lo anterior, lo importante es lo siguiente: ¿cuál es la perspectiva o criterio concluyente en la dilucidación de la naturaleza de la multa en la contratación administrativa? El objeto de esta primera sección es ofrecer un criterio concluyente de determinación. Este criterio puede calificarse como concluyente o comprehensivo en la medida en que, habiéndolo advertido, todas las demás cuestiones se siguen de este. Lo que argumentaremos es que este criterio es el hecho de que la autoridad administrativa sea quien cursa la multa. A partir de esto se sigue un modo de obrar administrativo que tiene carácter autoritativo, una relación jurídica con singulares atributos y regida por la justicia distributiva, la exigencia de un título de actuación que es la potestad, entre otros aspectos.

Finalmente, a modo de breve panorama jurisprudencial y dogmático, cabe decir que la Corte Suprema no ha tenido un criterio unívoco en esta materia. En efecto, esta magistratura ha declarado en ocasiones que "la aplicación de una multa impuesta por la administración en el marco de los contratos administrativos de la Ley No 19.886, constituye una sanción administrativa o bien una manifestación de la potestad sancionadora de la Administración" ${ }^{17}$. Sin embargo, también ha declarado que al multar en el contexto de un contrato administrativo, la autoridad administrativa "no se encuentra ejerciendo su 'potestad sancionadora' (...), por el contrario, (...) ejecuta una cláusula del contrato"18.

Por su parte, la Contraloría General de la República sí tiene asentada una doctrina, conforme a la cual la naturaleza jurídica de las multas es la de sanción contractual y no

\footnotetext{
15 Orrego (2019) p. 29.

16 Por ej. Cas Chile S.A. con Municipalidad de la Pintana (2019), C. $9{ }^{\circ}$.

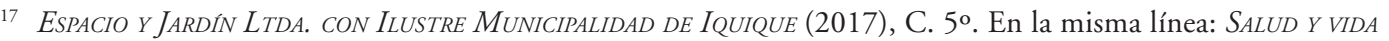
S.A y otros. con Junta NACIONAL DE AUXILIO ESCOLAR Y BECAS (2017), C. 37․

18 Cas Chile S.A. con Municipalidad de la Pintana (2019), C. $9{ }^{\circ}$.
} 
administrativa. Así, ha sostenido que "las estipulaciones contractuales que contiene multas asociadas al incumplimiento de las obligaciones convencionales tienen el carácter de cláusula penal"19.

A nivel dogmático (nacional), no hay una única respuesta a la pregunta sobre la naturaleza $^{20}$ ni tampoco respecto de qué tesis beneficia de mejor manera al particular contratista $^{21}$. Lo que sí está claro, es que esta incertidumbre jurídica afecta la eficiencia del sistema de contratación pública ${ }^{22}$.

\section{La AdMINISTRACIÓN DEL ESTADO EN CUANTO AUTORIDAD POLÍTICA}

La autoridad política es natural al hombre en la medida en que la sociedad política también lo es. La autoridad es condición sine qua non para que toda sociedad alcance su fin. Esto es así, pues sin una autoridad no sería posible resolver los desafíos y "problemas prácticos de coordinación que conciernen a todos en la comunidad"23.

La autoridad política, para ser eficaz, ha de actuar de un modo necesariamente potestativo. Ambos conceptos, autoridad y poder, están íntimamente implicados. Es cierto que bajo la distinción orsiana los conceptos de auctoritas y potestas pueden diferenciarse, entendiendo el primero como el "saber socialmente reconocido" y el segundo como el "poder socialmente reconocido". Con todo, a partir de este esquema "las funciones (...) ejecutivas son propias de la potestad"24.

Que el actuar de la autoridad sea potestativo significa "que lo que la persona revestida de dicha potestad dice o decide, en el ejercicio de ese poder o autoridad, impone un deber a otra persona" ${ }^{25}$. Así, lo específico del poder político es modificar la situación jurídica de quienes están sometidos a esa autoridad. En efecto, como dice un autor, "[1]as condiciones necesarias para el bien común son obligatorias con prescindencia de la voluntad de los sujetos beneficiados o vinculados" ${ }^{26}$. En otros términos, lo propio del poder político es suscitar obediencia en la población ${ }^{27}$.

En este marco conceptual, lo primero que define a la Administración del Estado es ser autoridad en una comunidad política, de lo que se sigue que su actuar es necesariamente potestativo. La consecuencia más importante de lo anterior es que se excluye que la Administración pueda actuar de modo facultativo.

\footnotetext{
19 Dictamen CGR 47.611 (2013). Concordante con No 30.003 (2014), No 4.508 (2013), No 11.961 (2018), entre otros.

20 Por ej. Moraga (2019) pp. 496-498; Lledó y Pardo (2015) pp. 58-65; Lara y García-Huidobro (2014) pp. 378-390; Corral (2012) p. 357; Bermúdez (2014) pp. 279-280.

21 Lledó y Pardo (2015) p. 65; Lara y García-Huidobro (2014) p. 371; García (2018).

22 Se han hecho propuestas de lege ferenda para aumentar la certeza, por ej. LlEdó y PARdo (2015) p. 71.

23 Finnis (2000) p. 274. Hay otras formas de argumentar la necesidad de la autoridad, por ej. ARANCIBIA (2017) 5 .

24 Domingo (1997) p. 197.

25 Orrego (2019) p. 86.

26 Arancibia (2017) p. 9.

27 Cruz (2006) p. 393
} 
Dos argumentos, aparte de lo dicho hasta ahora, refuerzan este punto. El primero dice relación con la singular posición en que se encuentra la Administración en relación con el particular, posición a la que no puede renunciar sin dejar de ser tal. El que la Administración y el particular ocupen su posición justa, además de definir el obrar justo de las partes, es condición para que la relación jurídica que se origina por la acción de la Administración se rija por la justicia del gobernante (distributiva) ${ }^{28}$. Con el concepto de posición justa apuntamos a "lo que cada uno es en ese orden social concreto en relación con los otros, su rol o función" ${ }^{29}$. La posición justa de la Administración es ser autoridad política: lo específico de la Administración es ocupar una posición de "supraordenación o verticalidad"30.

A partir de lo dicho se puede sostener que existe una verdadera distinción ontológica entre la Administración y el particular debido al interés que resguardan: "la autoridad, titular del interés del todo, y la persona, titular del interés de una de sus partes" ${ }^{31}$. Por el contrario, si se acepta la tesis de que la imposición de una multa es expresión de un obrar facultativo, se estaría reconociendo que la Administración puede obrar en un plano de igualdad con el particular, lo cual es incompatible con la distinción ontológica que hemos mencionado. De ahí que un principio básico de la contratación administrativa sea precisamente la "desigualdad" 32 . En efecto, la multa de la Administración no es expresión de un ejercicio facultativo, sino que, por el contrario, y de modo necesario, es expresión de un ejercicio potestativo, a pesar de que sea cursada en el contexto de la ejecución de un contrato administrativo.

Lo que hemos argumentado puede resumirse en el axioma tomista "el obrar sigue al ser" (operari sequitur esse). El modo de obrar, las características propias de las operaciones de la Administración, se siguen de su ser (autoridad pública), a lo cual no puede renunciar, ni aun cuando la relación en la que se desenvuelve pueda ser calificada como relación contractual $^{33}$. El ejemplo más claro de esta renuncia es que la Administración pretenda actuar de modo facultativo. Si la Administración obra negando el carácter potestativo de sus actuaciones al imponer una multa, significa que actúa obviando su calidad de autoridad, lo que carece de sentido. Constituye, en efecto, una contradicción en sus términos sostener que los actos de los órganos de la Administración del Estado pueden tener carácter facultativo. Como señala un autor: "esta posición supraordenadora en que se encuentra la autoridad trasciende todos sus actos" 34 .

Un segundo argumento para fundamentar que el actuar de la Administración es esencialmente autoritativo es el siguiente: la autoridad que detenta la Administración ha sido conferida por la comunidad política como un encargo que se comprende como indispensable para la realización del bien común. Debido a esto se sostiene que la actividad

\footnotetext{
28 Pieper (1988) pp. 136-161. Para el contrato administrativo: Arancibia (2019) pp. 43-47.

29 Orrego (2019) p. 29.

30 Arancibia (2017) p. 7.

31 Arancibia (2017) p. 7.

32 Bermúdez (2014) pp. 247-249.

33 Es cierto que la Administración no es una realidad natural. Con todo, nos parece que el axioma puede aplicarse analógicamente, pues esta invención humana posee contornos claros que justifican su poder.

34 Phillips (2020) p. 238.
} 
administrativa es una actividad "propiamente subordinada" 35 . El encargo tiene, en este sentido, un fundamento último, que es el poder de autodeterminación de toda sociedad respecto de su gobierno, lo que la Constitución denomina como "soberanía" ${ }^{36}$. El artículo 50 de la Constitución, en efecto, declara que la "soberanía reside esencialmente en la Nación". Luego, agrega que el "ejercicio de la soberanía se realiza (...) por las autoridades que esta Constitución establece" (por ej. capítulo IV. Gobierno).

Lo anterior significa, entre otras cosas, que las acciones de las autoridades administrativas deben considerarse como una manifestación de soberanía, de lo que se siguen dos cuestiones importantes. Primero, que toda actividad de la Administración es un encargo de la comunidad política. Segundo, que ese actuar siempre debe estar dirigido al fin que subyace al encargo, que es el bien de la comunidad toda. El problema radica en que si admitimos que la Administración puede actuar de un modo facultativo, admitimos también que dicho actuar no se realiza en virtud de la soberanía, pues, de lo contrario, sería necesariamente potestativo. Esto, según lo recién señalado, tiene como consecuencia que se priva a la Administración de su causa eficiente, que es el encargo por parte de la comunidad, lo que implica también borrar su causa final que es el bien común. Hay que recordar, en este contexto, que el contrato administrativo está orientado -como todas las actuaciones de la Administración- a la realización del bien común, es decir, a la satisfacción de necesidades públicas. De modo que, cuando la Administración celebra un contrato administrativo, fiscaliza su ejecución o sanciona su incumplimiento, lo que está haciendo es resguardar, no un interés particular, sino el bien común.

Se podría refutar lo dicho hasta ahora señalando que si bien es cierto que normalmente la Administración actúa de modo autoritativo, ello no siempre es así, y que una excepción es precisamente la multa en la contratación administrativa, actuación que escaparía de la forma tradicional ${ }^{37}$. Frente a ello, se podría replicar, con cierto fundamento metafísico, que la Administración -como todo ente- debe ser una para ser. La unidad de la Administración es ser una en cuanto autoridad. Esta unidad es el fundamento del carácter unitario de la relación jurídica público-privada ${ }^{38}$. Esta unidad, también, implica un modo de obrar único, que es el modo al cual hemos hecho referencia. Sin embargo, cuando se propone un modo de obrar que es incompatible con esa unidad, entonces necesariamente estamos hablando de otro sujeto. Dicho de otro modo: si aquel sujeto -la Administraciónes movido por dos o más principios que no solo son diferentes, sino que incompatibles entre sí, entonces no hay unidad y, por tanto, no nos estaríamos refiriendo a la misma autoridad (y, en este caso, no nos estaríamos refiriendo a autoridad alguna).

Queda por tratar un asunto menor, pero que puede generar cierta confusión, y que dice relación con la distinción entre actos de autoridad y actos de gestión. A esta distinción subyace la idea de que el derecho administrativo debe regir "a las Administraciones Públicas

\footnotetext{
35 Soto Kloss (2012) p. 35.

36 Sobre el concepto soberanía: SiLva (1997) Tomo I, pp. 212-222.

37 Lledó y Pardo (2015) p. 55.

38 Arancibia (2017) p. 6.
} 
siempre que -y solo cuando- actúan con 'poder' o 'autoridad', revestidas de imperium" 39 . Por ello es por lo que esta distinción se comprende como una limitación a la aplicación del derecho administrativo ${ }^{40}$. En efecto, existirían actos que, a pesar de ser orgánicamente autoritativos, serían de "simple gestión, actuando como un mero particular" «1 . En estos casos, el derecho que regiría la relación que se origina por aquellos actos de gestión sería el derecho privado.

La diferencia entre actos de gestión y actos de autoridad "encerraba ya un planteamiento entre la distinción entre acto y contrato, como las dos vías de actuación administrativa en Derecho" ${ }^{42}$. La distinción tenía, como se sabe, un alcance eminentemente procesal: "[d]e los actos administrativos únicamente podía conocer la autoridad administrativa; de los actos de gestión conocerán los tribunales, asimilándose a actividades de tipo privado" 43 . El contrato administrativo surge en el siglo XIX precisamente como una opción doctrinal y jurisprudencial que matiza esta distinción, reconociendo que hay ciertos contratos de la Administración que merecen un régimen jurídico diferente del derecho común ${ }^{44}$. No es el objeto de este trabajo ahondar en la evolución del contrato administrativo; basta decir que estas distinciones originarias han sido fuertemente superadas, lo que sucedió a la par de la independencia científica que adquirió el derecho administrativo ${ }^{45-46}$.

Desde un punto de vista dogmático, la doctrina que distingue entre actos de gestión y actos de autoridad debe rechazarse. En efecto, no puede la autoridad actuar "como si fuera" un particular, porque de hecho no lo es, ni en su fundamento (soberanía), ni en sus fines (bien común), ni en el modo en que obra (potestativo). Estos tres elementos son indisociables entre sí. Por lo demás, en nuestro país esta doctrina no tiene mayor alcance normativo. Es cierto que la Ley No 19.886 en su artículo $1^{\circ}$ dispone la aplicación de las normas de derecho privado, pero estas solo operan de modo supletorio (ahondaremos en esto en la segunda sección de este trabajo).

Lo que hemos expuesto en este apartado no agota en ningún caso la inabarcable reflexión que se ha hecho sobre la autoridad política desde los griegos ${ }^{47}$. Con todo, hemos intentado fundar la imposibilidad de comprender la autoridad administrativa separada de su actuar potestativo. Así, queda de manifiesto que hay un vínculo indisociable entre la noción orgánica y funcional de la Administración: la multa, al ser cursada por una autoridad administrativa, es una expresión (y tiene una naturaleza jurídica) necesariamente autoritativa, específicamente, potestativa sancionadora.

39 García de Enterría y Fernández (2006) Tomo I, p. 54. Se sugiere: García de Enterría (1963) pp. 101-103.

40 García de Enterría y Fernández (2006) Tomo I, p. 53.

41 García de Enterría y Fernández (2006) Tomo I, p. 54.

42 Oelckers (1979) p. 140.

43 Oelckers (1979) p. 140.

44 Loo (2018) p. 143. Se sugiere: García de Enterría y Fernández (2006) Tomo I, pp. 733-739.

45 Para un recorrido histórico: Loo (2018) pp. 143-149.

46 La distinción tuvo efectos en el régimen de responsabilidad: Pierry (2002) pp. 383-388.

47 Como introducción: Silva (1997) Tomo I, pp. 201-231. 


\section{LA FISONOMÍA JURÍDICA DE LA AUTORIDAD ADMINISTRATIVA}

Argumentar que el actuar administrativo es necesariamente potestativo es diferente a argumentar que requiere de una potestad que lo habilite. Lo primero apunta a una característica del obrar de la Administración, mientras que lo segundo al título que justifica dicho obrar. Habiendo tratado aquello en el apartado anterior, nos referiremos ahora a la cuestión de la potestad como título de la acción administrativa.

La Administración está llamada a actuar. Cierta doctrina, al precisar el núcleo dogmático del derecho administrativo, sostiene que se explica a partir de tres hechos que configuran la relación jurídica entre Administración y administrados, entre los cuales se encuentra "la acción administrativa, como origen de una relación jurídica" ${ }^{48}$. Sin acción administrativa, el derecho administrativo carecería de sentido. Así, se presenta la pregunta sobre la razón o causa del poder público, que define que dicho poder esté atribuido a una autoridad administrativa específica.

La respuesta es la potestad. La potestad es lo que posibilita que la Administración pueda obrar de un modo u otro. En efecto, "[t]oda acción administrativa se nos presenta así como ejercicio de un poder atribuido previamente por la Ley y por ella delimitado y construido" ${ }^{49}$. La potestad, en concreto, es la manifestación autoritativa más importante, dado que "expresa una inequívoca supremacía política" 50 .

Formalmente, la potestad está constituida por dos elementos: por un lado, el objeto del acto, su fin intrínseco (en el caso de la multa el objeto es sancionar) y, por otro, el sujeto u órgano encargado de ejercer la potestad ${ }^{51}$. La Constitución establece que el actuar válido de los órganos del Estado requiere que sea "dentro de su competencia" (artículo 7o), y la competencia es "la medida de la potestad que corresponde a cada órgano" 52.

Lo que ahora nos interesa es constatar que la potestad no solo es el título del actuar de la Administración, sino que también es aquello que le da su "fisonomía jurídica específica" ${ }^{3}$. Así, aquello que define la especie de autoridad política son las potestades que le han sido conferidas, pues esas potestades definen su fin y -como reza el adagio escolástico-finis causa formae: el fin es causa de la forma y la forma es aquello que especifica a una determinada realidad, como la autoridad administrativa de que se trate.

La Administración cumple con el fin general de promover el bien común "atendiendo necesidades públicas en forma continua y permanente y fomentando el desarrollo del país" (artículo 3을 Ley No 18.575). Este fin lo lleva a cabo mediante diferentes actividades que pueden comprenderse bajo la tradicional distinción de fomento, servicio público y policía ${ }^{54}$. Pero todo lo anterior no nos dice concretamente nada acerca de lo específico de una autoridad: de cómo debe obrar. Por ello, la misma norma dispone que la finalidad antes

\footnotetext{
48 Vergara (2010) p. 10.

49 García de Enterría y Fernández (2006) Tomo I, p. 478.

50 García de Enterría y Fernández (2006) Tomo I, p. 482.

51 Valdivia (2018) pp. 155-158.

52 Valdivia (2018) p. 217.

53 Valdivia (2018) p. 149.

54 Jordana de Pozas (1949) p. 42.
} 
mencionada, que se realiza por medio de diversas actividades, en concreto se lleva a cabo "a través del ejercicio de las atribuciones [potestades] que le confiere la Constitución y la ley”. Acudiendo nuevamente a ciertas nociones filosóficas, podría decirse que las potestades son los accidentes por medio de los cuales conocemos al sujeto que es la Administración, pues estas le dan su forma.

Sin potestad, por tanto, la Administración no encuentra el “'título' que permite dictar actos administrativos, que concretizan el poder de la administración” ${ }^{5}$. Agregamos nosotros, que la potestad también define la medida del obrar autoritativo. Ambos -título y medida- configuran, como hemos adelantado, la posición justa de cada autoridad administrativa. Así, si antes hemos rechazado que la Administración pueda actuar de modo facultativo, ahora también negamos que el título de dicho actuar pueda ser un derecho subjetivo. En otras palabras: si no hay potestad, no quiere decir que la Administración puede actuar en virtud de otro título, sino que sencillamente no puede obrar.

Aparte de lo dicho, hay dos consideraciones normativas que apoyan esta idea. Nuestra legislación define explícitamente el concepto "acto administrativo" (inciso segundo del artículo $3^{\circ}$, Ley No 19.880). Conforme a esta definición, la declaración de la voluntad que contiene el acto administrativo debe ser realizada "en el ejercicio de una potestad pública". De esto se sigue que las declaraciones de voluntad de la Administración que no se realizan en el ejercicio de una potestad pública no provocan efectos jurídicos y no pasan de ser una mera declaración ${ }^{56}$. Así, si bien el inciso final del artículo citado reconoce explícitamente la ejecutividad de los actos administrativos, ello debe ir necesariamente de la mano de la "atribución de potestades efectivas de intervención en el patrimonio o libertades de las personas" 57 . Sin la atribución de estas potestades, la ejecutividad, como atributo de los actos administrativos, no puede hacerse operativa.

Por otro lado, se encuentra el artículo $6^{\circ}$ de la Ley No 18.575, a partir del cual se puede concluir que las entidades que no forman parte de la Administración del Estado "no podrán, en caso alguno, ejercer potestades públicas". La razón de esto es evidente, y se desprende de lo que ya hemos señalado: la autoridad es precisamente tal en cuanto que ejerce potestades ${ }^{58}$. Con todo, de la lectura de este artículo también se puede arribar a otra conclusión: si bien carece de sentido que entidades fuera de la Administración actúen con potestades, también carece de sentido que los órganos de la Administración actúen como esas entidades que están fuera, es decir, que actúen sin potestades. Dicho de otro modo, la Administración no puede obrar a causa de acuerdos, ni el título de su acción puede ser una estipulación contractual, por lo que es inadmisible que pueda sancionar en virtud de una cláusula penal, dado que esta tiene naturaleza contractual.

Lo anterior apunta, en lo que nos ocupa, a que cualquier decisión que la autoridad pública adopte debe estar sustentada en una potestad si busca que efectivamente tenga

\footnotetext{
55 ValdiVia (2018) p. 151.

56 Valdivia (2018) p. 141.

57 Valdivia (2018) p. 206.

58 Con todo, hay entidades fuera de la Administración que tienen potestades, como la Corporación Nacional Forestal: VAldivia (2018) p. 150.
} 
carácter de acto de autoridad. En efecto, si la multa es una "reacción del ordenamiento frente a un hecho antijurídico" ${ }^{9}$, la Administración debe tener la "energía jurídica" 60 para cursarla. Esto que, según hemos dicho, es aplicable en general a la actuación de la Administración, es aún más importante para el caso de las sanciones, ya que en virtud de ellas la Administración hace uso de su poder de policía, ejerciendo coacción ${ }^{61}$.

Finalmente, cabe aludir a ciertas reflexiones a propósito del concepto de potestad y de la diferencia ontológica entre la Administración y el particular antes referida. Esta diferencia es lo que justifica las denominadas "cláusulas exorbitantes" 62 . En esta línea argumenta la Contraloría General de la República al señalar que "la Administración posee ciertas potestades exorbitantes, que difieren de las del derecho común por encontrarse comprometido el interés colectivo" ${ }^{63}$. Asimismo, diversos autores tratan la potestad sancionadora precisamente como un ejemplo de este tipo particular de "prerrogativas de poder público con que la Administración cuenta en sus contratos" ${ }^{64-65}$. Con todo, esta potestad no es propiamente contractual, precisamente porque su justificación se encuentra en la singularidad de la Administración como parte en el contrato ${ }^{66}$.

El equivalente privado de la potestad pública es el derecho subjetivo (del mismo modo que el equivalente del obrar potestativo es el obrar facultativo) ${ }^{67}$. En efecto, "[e]l concepto de potestad se perfila a través de su contraste dialéctico con el derecho subjetivo" ${ }^{68}$. Como señala otro autor, "el cumplimiento de los deberes impuestos por la autoridad no tiene su correlato en supuestos derechos del Estado en interés propio, sino en potestades en interés ajeno" ${ }^{69}$. La potestad se orienta al bien común y por ello es un poderdeber. Es deber ya que se detenta en beneficio de otro (la comunidad toda) ${ }^{70}$. Por ello es pertinente la definición de potestad según la cual es "aquel poder jurídico que, estando finalizado a beneficio de un tercero, constituye un deber de actuación para aquel a quien le ha sido conferido" ${ }^{71}$.

El que la potestad sea un deber implica que no puede renunciarse ${ }^{72}$. De este modo, si se configuran los hechos que estimulan el actuar conforme a la potestad, la autoridad administrativa no puede desistirse de actuar. Esto es precisamente lo opuesto al derecho subjetivo, que sí puede renunciarse, salvo prohibición expresa (artículo 12, Código Civil). Se

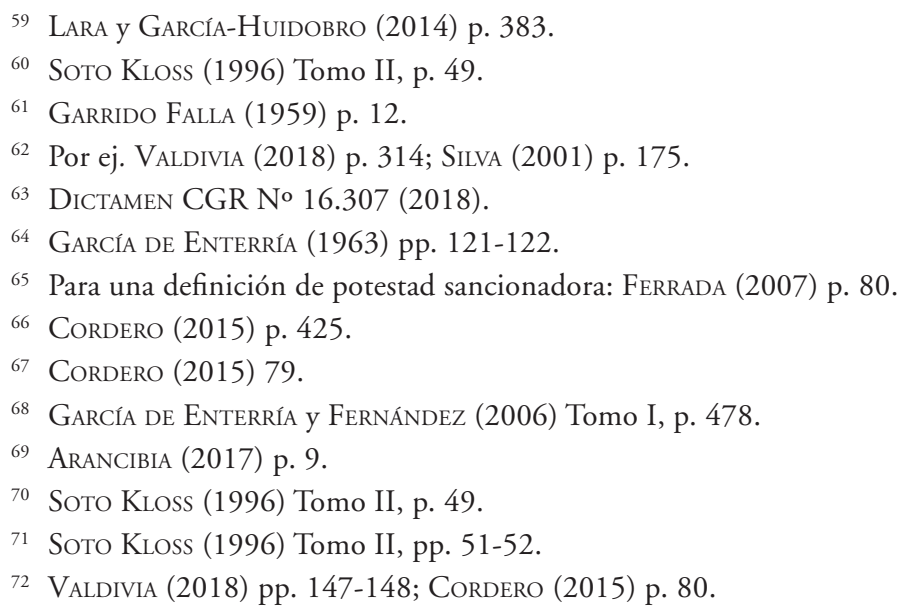


Aguilera Medina, Cristóbal অ "Naturaleza jurídica de las multas en la contratación administrativa..."

delinea aquí una diferencia fundamental entre la potestad sancionadora conferida por ley y los derechos contractuales emanados de una cláusula penal.

De lo anterior se sigue que la renuncia a ejercer la potestad sancionadora, cuando existe el deber de hacerlo, constituye una injusticia para con la sociedad. La explicación de esto se encuentra en la comprensión del actuar de la Administración como una actuar fundamentalmente orientado a "distribuir los bienes y cargas públicas de modo concreto en razón de una igualdad proporcional o geométrica entre las personas, según su mérito o demérito"73. En este marco, la multa debe entenderse como una carga pública merecida que se impone en razón de demérito. Si la Administración renuncia a imponer esta carga, se transgrede el principio de igualdad proporcional, concretándose una "discriminación arbitraria con respecto a quienes fueron, son o serán sujetos pasivos de la misma"74. Esto es así, porque la justicia que rige las actuaciones de la Administración, aun la denominada contractual, es la justicia distributiva ${ }^{75}$.

Por ende, el actuar de la Administración en el contexto de un contrato administrativo encuentra su título necesariamente en una potestad conferida por ley. En esta línea, el concepto de "cláusulas exorbitantes", dentro del cual se comprende a la potestad de multar (o la mal denominada cláusula penal), es equívoca por dos motivos. En primer lugar, pues el título para sancionar no puede ser una cláusula contractual. En segundo lugar, ya que no es correcto calificar los poderes que detenta la autoridad administrativa en la contratación como exorbitantes, es decir, excesivos o exagerados, dado que son coherentes con la naturaleza autoritativa de la Administración. En efecto, no son exorbitantes, precisamente porque lo que justifica dichas potestades es la desigualdad entre la autoridad administrativa y el particular. De ahí que nos parezca muy pertinente la conclusión de un autor, según la cual "al concebir el contrato administrativo como acto unilateral, aquellos atributos que resultaban excepcionales a la figura contractual pasan a ser inherentes. Nos referimos, especialmente, a las llamadas potestades exorbitantes" ${ }^{\prime 6}$. Comprender, pues, la autoridad administrativa como autoridad política, nos lleva a rechazar el adjetivo exorbitante que utiliza la doctrina para calificar las potestades que despliega cuando su acción se traduce en actos o contratos ${ }^{77}$.

\section{EL PRINCIPIO DE LEGALIDAD Y LA ACTUACIÓN SANCIONADORA EN LA CONTRATACIÓN ADMINISTRATIVA}

En la sección anterior hemos razonado en torno a dos argumentos fundamentales: que la actuación administrativa es esencialmente potestativa o autoritativa y que el título de dicha actuación es necesariamente una potestad. En virtud de estos dos argumentos, a su vez, refutamos dos tesis en relación con la naturaleza de la multa en la contratación administrativa: primero, que esta multa es manifestación de un obrar facultativo y, segundo, que

\footnotetext{
73 Arancibia (2016) p. 186.

74 Arancibia (2016) p. 186.

75 Arancibia (2019) p. 43.

76 Arancibia (2019) p. 48.

77 Ejemplo de las potestades administrativas como exorbitantes en FERrada (2007) pp. 75-76 o Flores (2019) p. 70.
} 
el título de dicha actuación son derechos subjetivos contractuales. En la presente sección, abordaremos una idea que se sigue de lo anterior, y que se refiere a la fuente de la potestad en virtud de la cual obra la Administración.

Esta sección seguirá el siguiente orden: en primer lugar, nos referiremos a grandes rasgos al principio de legalidad como fuente de atribución de potestades. En segundo lugar, abordaremos la distinción entre la convencionalidad y la legalidad en cuanto fuentes. En tercer lugar, examinaremos el problema de comprender que las potestades puedan consagrarse en las bases de licitación. En cuarto lugar, revisaremos la potestad de multar en la Ley No 19.886 y su Reglamento.

\section{El principio de legalidad y el pRoblema de la fUENTE de la potestad SANCIONADORA}

El principio de legalidad es una de las derivaciones jurídicas y políticas más paradigmáticas de la Revolución Francesa. En efecto, frente al poder absoluto, la propuesta que surge de la mano de este principio es una que busca su limitación y sometimiento a través de la ley, de modo de asegurar la libertad ${ }^{78}$. La ley surge, así, como "un instrumento directamente lanzado contra la estructura política del Estado absoluto: frente al poder personal y arbitrario, el ideal del gobierno por y en virtud de las leyes"79. Lo propio del poder público bajo el esquema del principio de legalidad es, pues, que constituye un poder conferido y que representa una manifestación declarada de la voluntad soberana ${ }^{80}$. Esta voluntad demarca el ámbito de acción de la Administración del Estado, de modo que las acciones administrativas están determinadas por esa voluntad general ${ }^{81}$. Así, la Administración está sometida a derecho, pero un derecho que es producto de lo que la nación escoge a través de las autoridades legislativas, por lo que no se autoriza a la Administración a perseguir libremente sus fines ${ }^{82}$, sino que debe someterse a lo que ha sido establecido en la legislación.

Nuestra normativa constitucional y legal hace eco de esta concepción originaria de la legalidad, que fue clave para el surgimiento del derecho administrativo moderno. Por un lado, es explícita la referencia -como ya lo hemos hecho notar-a la noción de soberanía del artículo $5^{\circ}$ de la Constitución. Por otro lado, el artículo $7^{\circ}$ es claro en que el actuar válido de los órganos del Estado requiere de una potestad conferida expresamente por la ley o la Constitución. El artículo $2^{\circ}$ de la Ley No 18.575 apunta en idéntica dirección. Lo mismo podría decirse respecto de la definición de acto administrativo del artículo $3^{\circ}$ de la Ley No 19.880, cuyo énfasis en el concepto de potestad pública "reafirma la vigencia del prin-

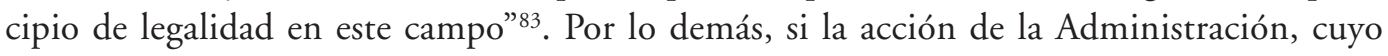
título es la potestad, se comprende como acción autoritativa, es decir, como una acción

\footnotetext{
78 Las leyes se entendían como leyes de libertad: García de EnTerría (1998) p. 25. También: Valdivia (2018) p. 153.

79 García de Enterría (1998) p. 21.

80 En la misma fuente se inspira el artículo 1 del Código Civil: ley como "declaración de la voluntad soberana".

81 García de Enterría (1998) pp. 21-24. Ver también Valdivia (2018) pp. 141-142.

82 Bermúdez (2014) p. 90.

83 Valdivia (2018) p. 191.
} 
que puede imponer obligaciones, necesariamente debe encontrar su fuente en la ley, que es precisamente fuente de obligaciones ${ }^{84}$. De ahí que, en última instancia, la multa en la contratación administrativa sea una reacción ante la infracción de una obligación contemplada primeramente en una norma legal y no a una obligación contemplada primeramente en la cláusula de un contrato administrativo.

De lo anterior se sigue que la fuente de la potestad en ningún caso puede ser un convenio o contrato. Como dice un autor: "toda la potestad tiene su origen directo en el ordenamiento jurídico y no en negocios jurídicos" ${ }^{85}$. En definitiva, a partir del principio de legalidad, podemos afirmar que los órganos del Estado solo pueden ejercer las potestades que expresamente han sido conferidas por la Constitución y las leyes ${ }^{86}$. Así, y en concordancia además con el principio de reserva legal, se puede concluir que "la única posibilidad que la Administración tiene para contar con poderes sancionatorios que afecten dicho ámbito es mediante una ley que así lo establezca" ${ }^{\text {87 }}$. Queda claro, de esta manera, que en los contratos públicos las multas por incumplimiento dispuestas en las bases no reúnen el requisito que establece el principio de legalidad ${ }^{88}$.

\section{PotestAd SANCIONADORA: LEGALIDAD VS. CONVENCIONALIDAD}

Sin perjuicio de lo anterior, se han formulado ciertos argumentos para superar la barrera de la legalidad, es decir, para sostener que la convencionalidad sí puede ser, en el caso de la contratación administrativa, fuente de potestades. Dos son los principales argumentos que se han expuesto a este respecto.

El primero puede formularse del siguiente modo: si el principio de legalidad fue creado para resguardar la libertad, ¿no es aún más coherente con este propósito el que la potestad que ejerce la autoridad pública encuentre su fuente y legitimidad en la aceptación libre por parte del particular que se somete a ella? Este argumento puede encontrar sustento en el denominado principio de cooperación, cuya materialización, entre otras, es la "participación del particular en el ejercicio de la potestad administrativa" 89 . De hecho, se ha planteado que una de las manifestaciones más claras del principio de cooperación es precisamente el fenómeno de la contratación administrativa ${ }^{90}$. De ahí que se puede sostener, como también lo ha hecho la Corte Suprema, que lo convenido, por el hecho de ser tal, "es ley para las partes" ${ }^{1}$. Esta tesis, en todo caso, no es novedosa en la jurisprudencia de la Corte Suprema, pues esta magistratura ha declarado en otras oportunidades que es "ple-

\footnotetext{
84 Agradecemos al profesor Jaime Arancibia por sus reflexiones sobre este punto.

35 Oelckers (1977) p. 128.

86 VAldivia (2018) p. 157.

87 Cordero (2014) pp. 410-411.

88 Lledó y Pardo (2015) p. 63.

89 Bermúdez (2014) p. 126.

90 Bermúdez (2014) p. 235.

91 Cas Chile S.A. con Municipalidad de la Pintana (2019), C. $10^{\circ}$.
} 
namente aplicable el artículo 1545 del Código Civil, puesto que al igual que un contrato entre particulares, el contrato administrativo es una ley para los contratantes"92.

El argumento, sin embargo, no es concluyente, menos aún en nuestro derecho público. La radicalidad normativa del artículo $7^{\circ}$ de la Constitución hace imposible pensar en una forma de atribución de potestades que no sea la ley o la Constitución, "ni aun a pretexto de circunstancias extraordinarias", como podría pensarse que es la necesidad de celebrar un contrato administrativo a fin de satisfacer una necesidad pública. En efecto, la disposición referida es suficientemente clara en que "[e]s al legislador a quien se le ha encargado, en exclusividad, la tarea de conferir potestades administrativas"93. Así, la convencionalidad que se argumenta como fuente de la cláusula que contiene la potestad de sancionar, no posee en el derecho administrativo la fuerza jurídica requerida para producir efectos imperativos. Como argumenta un autor ya citado: "[e]sta reserva de ley sale al paso de la doctrina que pretende validar las potestades contractuales creadas por normas administrativas (por ej. reglamento, bases de licitación) fundada en que la atribución legal de contratar comprende la de establecer otros poderes exorbitantes, en la medida que sean aceptados por el contratista (...) la mera aceptación del particular no bastaría para legitimar actuaciones extra-legem" 94 .

Pese a lo dicho, hay quienes han sostenido que la misma naturaleza de la actuación contractual da pie a confusiones: a la vez que se reconoce que el fundamento de esta figura es el consentimiento de las partes, la Administración sanciona a través de actos unilaterales. Así, la "Administración las ejecuta [las sanciones] a través de actos unilaterales que toman la forma de actos administrativos, por lo que no queda claro si está aplicando poderes públicos o no"95. A nuestro juicio, sin embargo, no hay duda de que al sancionar se están ejerciendo poderes públicos, pues el título que justifica dicha actuación sancionadora es una potestad.

El segundo argumento dice relación con lo siguiente: el contrato administrativo lo es porque una de sus partes es la Administración, pero ello no obsta a que deba regirse por criterios de derecho privado, lo que nos pone en un escenario distinto a la legalidad, donde priman los derechos pactados ${ }^{96}$. La Corte Suprema también en ocasiones ha seguido esta línea argumentativa, al declarar por ejemplo, que "las bases administrativas constituyen la fuente principal de los derechos y deberes de los contratantes a las que deben ajustarse". ${ }^{97}$ Esta tesis debe criticarse por dos motivos.

En primer lugar, ya que la Administración no tiene, en estricto rigor, derechos o facultades. En efecto, "las autoridades estatales tienen atribuidas funciones y no facultades, potestades (porque están establecidas en favor de una persona distinta del titular: la comunidad)"98. En esta línea, el concepto “derechos" del artículo 7 de la Constitución (“otra autoridad o derechos"), debe comprenderse como sinónimo de potestad y no de

92 GRISoifa y Compañia Limitada con Central de Abastecimiento del Sistema NaCional del SERVICIO DE SALUD (2003). Mismo razonamiento que el expuesto por la en el DiCTAMEN CGR No 34.523 (2013).

93 Soto Kloss (1996) Tomo II, p. 54.

94 Arancibia (2019) p. 42.

95 Lledó y Pardo (2015) p. 55.

96 Lara y García-Huidobro (2014) p. 374.

97 Cas Chile S.A. con Municipalidad de la Pintana (2019), C. $11^{\circ}$.

98 Aróstica (1994) p. 1. 
facultad ${ }^{99}$. Esto no quiere decir que la Administración no tenga margen alguno para ponderar discrecionalmente en materia contractual, pero sí que dicho margen está dado por la ley: "es también la ley, la que faculta a la Administración a actuar con un cierto grado de libertad al momento de determinar el contenido de la relación" ${ }^{100}$.

En segundo lugar, es un error también guiarse por los criterios de derecho privado, pues, desde el punto de vista normativo, y en el contexto de un contrato administrativo, las normas del derecho privado se aplican en defecto de las normas de Derecho Público, las cuales son supletorias respecto de las disposiciones de la Ley No 19.886 (artículo 1). Así, las normas de derecho privado no solo tienen el carácter de última ratio ${ }^{101}$, sino que deben ser compatibles con los criterios y principios que establece el derecho público. En lo que nos interesa, es evidente la incompatibilidad del principio de autonomía de la voluntad en materia contractual que rige el derecho privado con la institución de la potestad y su margen que es la legalidad ${ }^{102}$. Por otro lado, la justicia que rige la relación privada es la justicia conmutativa, y resultaría injusto y virtualmente imposible que la relación en la que participa la Administración sea regida por una justicia diferente a la distributiva, dado que ella está llamada a distribuir.

\section{POTESTAD SANCIONADORA EN LAS BASES ADMINISTRATIVAS}

Otro aspecto que nos parece necesario analizar, dice relación con la tesis de que la facultad de multar se encontraría en las bases administrativas. Entre quienes han defendido esta postura se encuentra la Contraloría General de la República. La Contraloría, para argumentar en contra de la tesis de que las multas en la contratación administrativa son manifestación de potestad sancionadora, sostiene que estas no pueden ser sino ejercicio de derechos contractuales, pues tienen "fundamento en una estipulación libremente pactada por las partes en el contrato correspondiente, en el carácter de cláusula penal y que, por ende, no constituye una multa administrativa que pueda imponerse unilateralmente por la autoridad, toda vez que ello requiere de una norma legal que la autorice"103. Este razonamiento presenta dos tensiones.

Primero, da por supuesto lo que precisamente es controvertido. En efecto, lo controvertido es la naturaleza jurídica de la multa, pues de ello se deriva si es posible (o no) su imposición unilateral y si requiere (o no) una norma legal que autorice su aplicación. Ahora bien, conforme a lo que hemos revisado, podríamos proponer una conclusión diferente: como quiera que la multa es manifestación de la potestad sancionadora de la Administración, esta requiere necesariamente de una norma legal que la autorice. En este sentido, si bien las bases pueden contener ciertos "elementos configuradores de una potestad" 104 , esta debe estar expresamente conferida por la ley.

\footnotetext{
99 Valdivia (2018) p. 157.

100 Oelckers (1983) pp. 154-155.

101 Lara y García-Huidobro (2014) p. 375.

102 Aróstica (1994) pp. 10-11.

103 Dictamen CGR No 31.616 (1989).

104 Arancibia (2016) p. 184.
} 
La segunda tensión es la existencia de -por así decir- una especie de trampa jurídica que subyace a la tesis según la cual la potestad sancionadora puede estar contemplada y conferida en las bases administrativas. En efecto, las bases son documentos "aprobados por la autoridad competente"105. Esto quiere decir que no son fruto de la convención, sino que son "preparadas por la propia Administración, usualmente sin dar participación a quienes serán los interesados en el proceso licitatorio" ${ }^{106}$. La Corte Suprema, de hecho, ha definido las bases como "el conjunto de cláusulas formuladas unilateralmente por el licitante"107. Esto nos lleva a sostener dos cosas. En primer lugar, que, incluso de ser cierto que la convencionalidad puede ser fuente de potestades, en este caso esta convencionalidad no existiría, o no con toda la intensidad que se ha defendido, pues las bases son fruto de la unilateralidad de la Administración. En segundo lugar, y más importante aún, debemos decir que la idea de que las bases sean la fuente de la potestad de multar esconde la trampa jurídica que más arriba anunciábamos: significa reconocer que la propia Administración puede atribuirse potestades. Esto, por supuesto, pugna directamente con el principio de legalidad, en cuanto principio limitador del poder.

En relación con lo anterior, quisiéramos hacer notar una contradicción que a nuestro juicio esconde la argumentación que la Contraloría ha sostenido en su jurisprudencia. En efecto, la tesis central de la Contraloría es la siguiente: "las estipulaciones contractuales que contienen multas asociadas al incumplimiento de las obligaciones convencionales tienen el carácter de cláusula penal, la que se encuentra definida por el Código Civil en su artículo $1535 " 108$. A la vez, sin embargo, ha sostenido que la "Administración posee ciertas potestades exorbitantes, que difieren de las del derecho común por encontrarse comprometido el interés colectivo, tales como la facultad de elaborar las bases de licitación"109. Nos parece que ambas declaraciones son incompatibles entre sí: si aceptamos que la elaboración de las bases es una potestad exorbitante, la fuente de las potestades que se incorporan en las bases (como la de sancionar) debe ser necesariamente la ley, pues las bases solo pueden contemplar lo que la ley le permite a la autoridad administrativa establecer en el ejercicio de la potestad de elaborar las bases. En otras palabras, la Administración no puede incorporar en las bases administrativas ninguna potestad que no se le haya conferido previamente en virtud de una ley y, además, en la medida en que la ley le permita expresamente ejercerla en el contexto de la ejecución de un contrato administrativo.

Esto significa que la fuerza jurídica que detenta la Administración para sancionar las infracciones al contrato no encuentra su fuente en el consenso que este (supuestamente) implica, sino que está dada por la decisión unilateral de la administración: las bases son actos administrativos. De ahí que es un error denominar "cláusula penal” a la cláusula con-

\footnotetext{
105 Artículo 2o número 3, decreto No 250 de 2004, Ministerio de Hacienda.

106 Moraga (2019) p. 344.

107 Seguridad INTEGRAL TMI S.A. con Hospital BARRos LuCO (2015).

108 Dictamen CGR 47.611 (2013).

109 Dictamen CGR 16.307 (2008).
} 
tractual que contempla la potestad sancionadora, pues la cláusula penal es de origen convencional $^{110}$, y la potestad sancionadora es de origen legal y unilateral.

Debido a lo anterior, también debe rechazarse cualquier intento por legitimar la potestad sancionadora contemplada en las bases en virtud del principio de estricta sujeción a las bases (artículo 10 inciso tercero de la Ley No 19.886). Este principio implica una observancia marcadamente rigurosa de lo establecido en las bases administrativas y técnicas ${ }^{111}$. Con todo, esta observancia solo cobra fuerza en la medida en que aquello que se dispone en las bases tenga, a su vez, una fuente legal. En efecto: el problema de la legalidad de la potestad es anterior al problema de la estricta sujeción a las bases, de modo que no es posible resolver aquel aludiendo a este.

Finalmente, nos parece necesario hacer una última precisión en miras a distinguir tres aspectos que suelen confundirse en esta discusión. La multa en la contratación administrativa opera sobre la base de dos supuestos materiales y un fundamento formal. Por un lado, es evidente que la multa que cursa la Administración tiene como supuesto material la infracción del contrato por parte del particular. El segundo supuesto material es el sometimiento voluntario del particular a las bases administrativas a través de la celebración del contrato. Finalmente, se encuentra el que podríamos denominar fundamento formal, que dice relación con la justificación del poder que se despliega, que es la potestad. Estos tres aspectos no deben confundirse en lo que se refiere al fundamento de la aplicación de la multa, pues si bien la multa es una reacción ante la infracción, que puede aplicarse a un determinado particular ya que tiene la calidad de contratista, su fundamento formal último es la ley que confiere la potestad de sancionar la infracción.

\section{Normativa VIGENTE}

En este último apartado analizaremos la multa en la contratación administrativa de acuerdo a las normas que se establecen en la Ley No 19.886 y su Reglamento. También revisaremos el problema de atribuciones de potestades implícitas.

\subsection{Ley $N^{o} 19.886$}

A partir de lo expuesto en el apartado anterior podemos concluir que las cláusulas que contemplan la potestad de multar las infracciones al contrato son ilegales e inconstitucionales, debido a que estas no pueden ser la fuente de la potestad sancionadora. Sin embargo, se podría rebatir esta conclusión, argumentando que las cláusulas no son la fuente de la potestad sancionadora, sino que es la Ley No 19.886. La Contraloría General de la República, por ejemplo, ha sostenido que "la Ley No 19.886 reconoce la posibilidad que la Administración contemple multas en su contratación de bienes y servicios, pero no la regula” ${ }^{112}$.

La ley No 19.886 menciona en tres oportunidades el vocablo multa. Para los efectos de lo que nos interesa, la mención que debemos analizar es la que se encuentra en el inciso

\footnotetext{
110 Corral (2012) pp. 9-12.

111 Valdivia (2018) p. 305.

112 Dictamen CGR No 47.611 (2013).
} 
tercero del artículo 11: “[c] on cargo a estas cauciones podrán hacerse efectivas las multas y demás sanciones que afecten a los contratistas".

Como se puede advertir, este inciso tiene por fin facilitar el cobro de las multas y otras sanciones. Sin embargo, no constituye una norma cuyo objeto sea conferir la potestad sancionadora a los órganos de la Administración que celebran contratos. En efecto, no parece ser esta una disposición que constituya un "previo apoderamiento legal"113 para la imposición unilateral de sanciones al contratista que infringe las obligaciones contempladas en el contrato administrativo ${ }^{114}$. Dicho de otra manera, no es posible argumentar a partir de esta norma que la Administración tenga la autorización legal que exige el artículo 7 de la Constitución para multar en el contexto de la contratación administrativa.

La historia de la ley tampoco nos ofrece mayores luces al respecto. El Mensaje que concluyó en la Ley No 19.886, al referirse a las facultades contractuales que posee la Administración, menciona la de "imponer administrativamente las multas pactadas" 115 . Esta expresión no se contempló en ninguno de los artículos de la iniciativa en su versión original ni en ninguna de las versiones del proyecto a lo largo de su tramitación. Lo que sí se contempló en la iniciativa original, fue la potestad de la Administración de "imponer administrativamente las multas que establezcan las bases" ${ }^{116}$. Esta disposición, sin embargo, que podría haber cumplido el estándar exigido por el principio de legalidad, solo prosperó hasta el estudio del proyecto en la Comisión de Hacienda de la Cámara de Diputados (primer trámite constitucional), en la cual se agregó, luego de la palabra "multa", la expresión "y demás sanciones", y se borró la frase "que establezcan las bases"117.

No habiendo una regulación expresa en la Ley No 19.886, nos parece que la potestad de sancionar no ha sido conferida a las autoridades administrativas que celebran contratos en virtud de esta ley. En este sentido, las controversias teóricas y prácticas tienen como causa precisamente el silencio del legislador a la hora de conferir la potestad de multar ${ }^{118}$.

\subsection{Potestad implicita de sancionar las infracciones a los contratos administrativos}

El inciso segundo del artículo $7^{\circ}$ de la Constitución contempla el término "expresamente", que describe el modo en que deben ser conferidas las potestades. La expresión no es casual, e introduce una exigencia normativa importante. De ahí que el artículo $2^{\circ}$ de la Ley No 18.575 haya recogido este adjetivo. Desde el punto de vista jurídico, la voz expresamente significa que debe estar de tal manera delimitada la potestad "que se configure debidamente el poder jurídico de actuación que se atribuye a un órgano determinado, y que, precisamente, le va a permitir actuar en un sentido dado para obtener el fin de bien común

\footnotetext{
113 Cordero (2014) p. 410.

114 No nos referiremos, porque escapa del propósito del trabajo, al problema de la tipicidad de las infracciones.

Se sugiere: Cordero (2014) pp. 415-420 y LlEdó y PARdo (2015) p. 61.

115 Historia de la Ley No 19.886 , p. 11.

116 Artículo 25, Mensaje del Presidente de la República (Histórica de la Ley No 19.886, 18).

117 Primer y segundo informe de la Comisión de Hacienda (Historia de la Ley No 19.886, 35 y 59).

118 Lledó y Pardo (2015) p. 59.
} 
para el cual existe y para lo cual se le atribuye"119. Luego, cabe concluir que "[s]in esa expresa atribución de una potestad, simplemente no puede actuar" ${ }^{120}$.

Frente este escenario, cierta doctrina sostiene que Ley No 19.886 reconocería la procedencia de las multas "en forma indirecta, al ser mencionadas a propósito de otras instituciones de la contratación administrativa" ${ }^{21}$. No compartimos esta tesis. Por un lado, no es suficiente el reconocimiento en forma indirecta. Por otro lado, aun si se aceptara la suficiencia del reconocimiento indirecto de una potestad, tampoco compartimos que esto ocurra. Para que exista un reconocimiento indirecto de algo debe existir una base textual que dé a entender que se está reconociendo ese algo, aunque no sea de un modo claro (indirecto). En este caso, a pesar de que la disposición aludida se refiere explícitamente a las sanciones y multas, de ella no se puede desprender que está "reconociendo" la potestad de multar, en el sentido de que la está estableciendo, admitiendo o, en términos jurídicos, confiriendo. Por otro lado, la significación "indirecta" de algo es sinónimo de "no significarlo explícita o claramente"122, lo cual contraviene el término "expresamente" del artículo

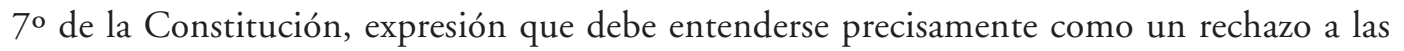
potestades implícitas.

Otra doctrina define las prerrogativas o potestades implícitas como "un poder exorbitante de la Administración que se incluye dentro del marco jurídico del contrato (ley o reglamento), no obstante que no se encuentre explicitado en su texto" ${ }^{123}$. De este modo, se intenta diferenciar lo "implícito" de lo "presumible o tácito", siendo esto último -y no lo primero- absolutamente incompatibles con el régimen contractual administrativo vigente ${ }^{124}$.

La distinción nos parece confusa. Si la potestad está incluida expresamente en la ley, y no se contempla en las cláusulas del contrato (que pareciera ser la hipótesis a que se alude), no parece que nos encontremos ante una potestad o prerrogativa "implícita". Que una potestad no esté contemplada en las bases administrativas, pero sí en la ley, no significa que el contrato la incorpore de un modo poco claro o no expreso (implícito), sino que significa, sencillamente, que no la contempla; pero desde el punto de vista jurídico esto no es un problema, pues es la ley la que confiere potestades, y ya las habría conferido antes de la celebración del contrato.

Sin perjuicio de lo anterior, un argumento que se podría esgrimir para reconocer la potestad sancionadora implícita en la ejecución de contratos administrativos es el siguiente: si el legislador ha conferido la potestad para celebrar contratos, naturalmente también ha conferido potestad para sancionar las infracciones. Esto se argumenta, pues "[1] a potestad sancionadora de la Administración, que ejerce dentro de un escenario de contratación, es el correlato necesario de sus atribuciones de control, fiscalización y dirección, puesto que de nada servirían estas sin un instrumento de coacción efectiva” ${ }^{125}$. Así, no sería necesario que

\footnotetext{
119 Soto Kloss (1996) Tomo II, p. 49.

120 Soto Kloss (1996) Tomo II, p. 49.

121 Lara y García-Huidobro (2014) p. 379.

122 Diccionario de la lengua española (2001) 22a edición, acepción segunda.

123 Moraga (2019) p. 474.

124 Moraga (2019) p. 474.

125 Moraga (2019) p. 492.
} 
la ley expresamente le atribuyera a la Administración el poder de sancionar las infracciones, pues esto viene dado al conferir el poder de contratar. El argumento nos parece equivocado por dos motivos. En primer lugar, pues, para sostenerlo, debemos aceptar la idea de la potestad implícita que ya hemos desechado. En segundo lugar, ya que del hecho de que una potestad sea necesaria, en cuanto correlato para el correcto ejercicio de otra potestad, no se sigue que la primera esté contenida en la segunda, aun implícitamente, pues se trata de dos poderes distintos. Así, por ejemplo, para la correcta ejecución del contrato es necesario poderes de fiscalización, pero lógicamente las potestades de contratar y fiscalizar son diversas: su objeto es diferente. En palabras de un autor ya citado: "el poder legal de imponer cargas públicas, sujetas o no a aceptación, no comprende el de modificarlas, sancionar su incumplimiento o terminarlas unilateralmente. Tales prerrogativas son distintas y, por tanto, requieren también de poder legal"126.

Por lo demás, aun si aceptáramos, para efectos de este argumento, como cierta la tesis de que las multas son cursadas en el ejercicio de derechos contemplados en las cláusulas del contrato, debemos desechar la tesis de que estas están implícitas, pues aquella que permitiría la sanción unilateral constituiría una cláusula diferente, que no sería posible comprender como un elemento de la naturaleza del contrato (sobre todo si seguimos la tesis según la cual la cláusula penal "no es necesariamente una disposición inserta dentro del contenido global de un contrato" ${ }^{127}$ ).

Finalmente, hay quienes sostienen que el poder de sancionar estaría conferido naturalmente a la Administración por el hecho de ser autoridad pública. Así, se argumenta que incorporar potestades exorbitantes en los contratos administrativos sería una redundancia: en la medida en que estos poderes los posee la Administración en cuanto autoridad pública, "estas prerrogativas pertenecen al ius cogens" 128 . Esto, sin embargo, pugna con la exigencia del artículo $7^{\circ}$ de la Constitución. Además, desconoce que la reserva legal que se establece es "tanto para la estructura de la potestad administrativa como el ámbito de su ejercicio"129. Por último, a este argumento subyace una lógica incompatible con la idea del principio de legalidad, que es devolver al poder ejecutivo una soberanía que no se origina en la voluntad general, sino en la detentación fáctica del poder ${ }^{130}$.

\subsection{Reglamento}

Como última cuestión, para salvar la potestad sancionadora de la Administración frente a la infracción de un contrato administrativo, podemos aludir a la tesis de que los reglamentos pueden complementar ampliamente lo dispuesto en la ley. Sin embargo, el Reglamento de la Ley No 19.886 tampoco da luces para resolver este problema. El inciso final del artículo 22 reitera lo que dispone el inciso tercero del artículo 11 de la ley. Por su parte,

\footnotetext{
26 ARANCibia (2019) p. 42.

127 Corral (2012) p. 9.

128 Moraga (2019) p. 492.

129 Soto Kloss (1996) Tomo II, p. 54.

130 Moraga (2019) p. 474.
} 
Aguilera Medina, Cristóbal অ "Naturaleza jurídica de las multas en la contratación administrativa..."

el artículo 23 número 4, que en situaciones se ha utilizado como argumento ${ }^{131}$, es demasiado abierto y ambiguo como para comprenderse como norma habilitante.

El artículo 79 ter merece algunos comentarios especiales, pues contiene disposiciones de mayor densidad. Por un lado, y en relación con lo analizado en la sección anterior, es indudable que este artículo se refiere a la multa como sanción administrativa: "las regulaciones allí contenidas parecen dirigirse más a una manera correcta de ejercer el ius puniendi, antes que de una cláusula penal" ${ }^{132}$. A su vez, en la parte final del inciso tercero se dispone que en contra de "dicha resolución procederán los recursos dispuesto en la Ley No 19.880". Esta frase es reveladora, pues si la naturaleza de la multa fuese de cláusula penal, al cursarla no se estaría ejerciendo una potestad sino un derecho contractual. Tal acto de cursar una multa, entonces, no constituiría un acto administrativo. En este sentido, no deberían proceder los recursos de la ley No 19.880; pero, como proceden, es dable concluir que sí se trata de un acto administrativo, es decir, de potestad pública.

Por otro lado, este artículo dispone el modo en que deben ejercerse las sanciones que ahí se establecen. Así, el inciso segundo dispone que "las medidas que se establezcan deberán ser proporcionales a la gravedad del incumplimiento". Luego, específicamente respecto de las multas, el inciso norma que "[s]i la medida a aplicar consistiere en el cobro de multas, las bases y el contrato deberán fijar un tope máximo para su aplicación”. Finalmente, el inciso tercero dispone que "las bases y el contrato deberán contemplar un procedimiento para aplicación de las medidas establecidas (...) que respete los principios de contradictoriedad e impugnabilidad”.

Esta regulación, por cierto, cumple en mayor medida los estándares de densidad normativa que se requieren para constituir una norma habilitante de potestad sancionadora. Sin embargo, su defecto es su naturaleza reglamentaria. Así, si bien el artículo en cuestión puede leerse como una disposición que atribuye competencias sancionadoras a la Administración, y entrega su determinación a las bases de licitación, esto corresponde a materia de "estricta reserva legal"133.

En este punto, podemos ver que la Administración -por así decirlo- utiliza el Reglamento y las bases como una válvula de escape ante la ausencia de regulación legal sobre la materia, con el objeto de hacer aplicable el régimen de contratación, pues se comprende que las atribuciones de control, fiscalización y dirección del contrato requieren de un necesario correlato que es precisamente la potestad sancionadora ${ }^{134}$.

\section{CONCLUSIONES}

Podemos enumerar las siguientes conclusiones:

1. La pregunta sobre la naturaleza jurídica de la multa en la contratación administrativa se enmarca dentro de una discusión anterior, que dice relación con el problema

\footnotetext{
131 Dictamen CGR No 48.732 (2012).

132 Moraga (2019) p. 497.

133 Cordero (2014) p. 413.

134 Moraga (2019) p. 492.
} 
sobre la naturaleza del contrato administrativo. La pregunta sobre la naturaleza jurídica de la multa aborda diversas aristas y disyuntivas. Para responderla de modo satisfactorio, es necesario identificar un criterio concluyente. Este criterio es la singularidad de la Administración como parte del contrato administrativo, de lo cual se concluye que la multa es una sanción administrativa y no contractual.

2. La autoridad administrativa es autoridad política, de lo que se sigue que su actuar es esencialmente potestativo. Se niega la posibilidad de que la Administración pueda obrar facultativamente. A su vez, el título del actuar autoritativo de la Administración es necesariamente una potestad. Sin potestad la autoridad administrativa no puede actuar, pues no tiene otro principio que se lo permita. De esto se sigue que nunca sea lícito justificar el actuar de la Administración en virtud de un título que constituya derechos subjetivos: la aplicación de la multa no puede justificarse en el ejercicio de una supuesta cláusula penal.

3. El que el título del actuar autoritativo de la Administración sea una potestad, implica que esta deba ser necesariamente otorgada por ley. La fuente de las potestades no puede en ningún caso ser una convención o contrato. La potestad, a su vez, debe estar conferida expresamente por la ley, de modo que se rechaza la posibilidad de las potestades implícitas. La Ley No 19.886 y, en particular, el artículo 11 de la misma, no confiere expresamente a la autoridad administrativa la potestad de sancionar con una multa las infracciones al contrato administrativo. Siendo así, la autoridad administrativa no está habilitada, en virtud de este cuerpo legal, para sancionar unilateralmente al contratista con una multa. Se rechaza, finalmente, la posibilidad de encontrar la fuente de esta potestad en el reglamento, precisamente por su naturaleza de norma administrativa (y no legal), a pesar de su mayor densidad normativa.

\section{BIBLIOGRAFÍA CITADA}

Alvira, Tomás; Clavell, Luis y Melendo, Tomás (2001): Metafísica (Pamplona, Ediciones Universidad de Navarra).

Arancibia Mattar, Jaime (2016): "Los puntos de prueba en los litigios de impugnación de los actos administrativos", en Arancibia Mattar, Jaime y Romero Seguel, Alejandro (coords.), La prueba en la litigación pública (Santiago, Librotecnia) pp. 161-190.

Arancibia Mattar, Jaime (2017): "La relación jurídica público-privada: iter conceptual, atributos y criterios", en SоTO Kloss, Eduardo (edit.), El derecho Administrativo y la protección de las personas. Libro Homenaje a 30 años de docencia del profesor Ramiro Mendoza en la UC (Santiago, Ediciones UC) pp. 1-15.

Arancibia Mattar, Jaime (2019): "Naturaleza y justicia de los contratos administrativos", Revista de Derecho Administrativo Económico, No 30: pp. 27-53.

Aróstica Maldonado, Iván (1994): "La actividad jurídica de la Administración". Curso de Derecho administrativo. El acto Administrativo. Cátedra del profesor Iván Aróstica. Lección 1 , introductoria.

Bermúdez Soto, Jorge (2014): Derecho Administrativo General (Santiago, Thomson Reuters, tercera edición).

Cordero Vega, Luis (2015): Lecciones de Derecho Administrativo (Santiago, Thomson Reuters). 
Cordero Quinzacara, Eduardo (2014): "Los principios que rigen la potestad sancionadora de la Administración en el derecho chileno", Revista de Derecho de la Pontificia Universidad Católica de Valparaiso, No 42: pp. 399-439.

Corral Talciani, Hernán (2012): La "cláusula penal". Función y eficacia del contrato penal en el Derecho chileno (Santiago, Editorial Jurídica de Chile).

Cruz Prados, Alfredo (2006): Ethos y Polis. Bases para una reconstrucción de la filosofía política (Pamplona, Ediciones Universidad de Navarra).

Diccionario De la lengua española (2001): Disponible en http://www.rae.es/rae.html. Fecha de consulta: 8 septiembre 2020 .

Domingo, Rafael (1997): "El binomio “auctoritas-potestas" en el Derecho romano y moderno”, Revista Persona y Derecho, No 37: pp. 183-195.

Ferrada Bórquez, Juan Carlos (2007): "Las potestades y privilegios de la Administración pública en el régimen administrativo chileno", Revista de Derecho (Valdivia), vol. XX, No 2: pp. 69-94.

FinNis, John (1980): Ley Natural y Derechos Naturales (trad. Cristóbal Orrego Sánchez, Buenos Aires, Abeledo-Perrot).

Flores Rivas, Juan Carlos (2019): "Revisión de los contratos administrativos: el adecuado equilibrio entre potestades exorbitantes y los derechos contractuales", Revista de Derecho de la Pontificia Universidad Católica de Valparaíso, vol. 53, No 2: pp. 67-98.

García García, José (2018): "Naturaleza jurídica de las multas en la contratación administrativa”. Disponible en: https:/www.elmercurio.com/Legal/Noticias/Analisis-Juridico/2018/07/26/Naturaleza-juridica-de-las-multas-en-la-contratacion-administrativa. aspx. Fecha de consulta: 8 septiembre 2020.

García de Enterría, Eduardo (1963): "La figura del contrato administrativo", Revista de administración pública, No 4: pp. 99-128.

García de Enterría, Eduardo (1998): Revolución Francesa y Administración Contemporánea (Madrid, Civitas).

García de Enterría, Eduardo y Fernández, Tomás-Ramón (2006): Curso de Derecho Administrativo, Tomo I (Lima, Editorial Temis).

Garrido Falla, Fernando (1959): "Los medios de la policía y la teoría de las sanciones administrativas”, Revista de Administración Pública, No 28: pp. 11-50.

Historia de LA Ley No 19.886 (2003): Disponible en https:/www.bcn.cl/historiadelaley/ nc/historia-de-la-ley/5860/. Fecha de consulta: 8 septiembre 2020.

Huergo Lora, Alejandro (1998): Los contratos sobre los actos y las potestades administrativas (Madrid, Civitas).

Jornada de Pozas, Luis (1949): "Ensayo de una teoría del fomento en el Derecho Administrativo", Revista de estudios políticos, No 48: pp. 41-54.

lara Arroyo, José y García-Huidobro Herrera, Luis (2014): "Naturaleza Jurídica y Proporcionalidad de las Multas en la Contratación Administrativa bajo la Ley No 19.886", en Arancibia Matta, Jaime y Alarcón Jaña, Pablo (coords.), Sanciones Administrativas, $X$ Jornadas de Derecho Administrativo (Santiago, LegalPublishing) pp. 369-400. 
Loo Gutiérrez, Martín (2018): "Posicionamiento dogmático de la actividad contractual de la Administración del Estado", Revista de Derecho de la Pontificia Universidad Católica de Valparaiso, vol. 50, No 1: pp. 129-155.

Lledó Veloso, Camilo y Pardo Donoso, José (2015): “Sistema de sanciones por incumplimiento en los contratos públicos de suministro y prestación de servicios: la incerteza como un problema de política pública”, Revista de Derecho Público, No 82: pp. 53-77.

Moraga Klenner, Claudio (2019): Contratación administrativa (Santiago, Thomson Reuters, segunda edición).

Oelckers Camus, Osvaldo (1977): "El principio de legalidad como supuesto de la potestad administrativa", Revista de Derecho de la Pontificia Universidad Católica de Valparaíso, No 1: pp. 111-151.

Oelckers Camus, Osvaldo (1979): "En torno al concepto de contrato administrativo", Revista de Derecho de la Pontificia Universidad Católica de Valparaíso, No 3: pp. 135-160.

Oelckers Camus, Osvaldo (1983): "Los principios informadores de la contratación administrativa", Revista de Derecho de la Pontificia Universidad Católica de Valparaíso, No 7: pp. 151-164.

Orrego Sánchez, Cristóbal (2019): Derecho: Conceptos Fundamentales (Santiago, Ediciones del Círculo de Santiago).

Ramos Pazos, René (2004): De las obligaciones (Santiago, LexisNexis).

Phillips LeTelier, Jaime (2020): La protección de expectativas en el derecho administrativo chileno. Una propuesta para la aplicación del principio de protección de la confianza (Valencia, Tirant lo Blanch).

Pieper, Joseph (1988): Las virtudes fundamentales (Madrid, Rialp).

Pierry Arrau, Pedro (2002): "Las transformaciones del Derecho Administrativo en el siglo XX", Revista de Derecho de la Pontificia Universidad Católica de Valparaíso, No 23: pp. 377-404.

Silva Bascuñan, Alejandro (1997): Tratado de Derecho Constitucional, Tomo I (Santiago, Editorial Jurídica de Chile).

Silva Cimma, Enrique (2001): Derecho Administrativo Chile y Comparado. Actos, Contratos y Bienes (Santiago, Editorial Jurídica de Chile).

Soto KLoss, Eduardo (1996): Derecho Administrativo. Bases fundamentales, Tomo II (Santiago, Editorial Jurídica de Chile).

Sото Kloss, Eduardo (2012): Derecho Administrativo. Temas Fundamentales (Santiago, AbeledoPerrot-Thomson Reuters).

Valdivia Olivares, José (2018): Manual de Derecho Administrativo (Valencia, Tirant lo Blanch).

Vergara Blanco, Alejandro (2010): El Derecho Administrativo como Sistema Autónomo (Santiago, AbeledoPerrot).

\section{NORMAS CITADAS}


Aguilera Medina, Cristóbal " "Naturaleza jurídica de las multas en la contratación administrativa...”

Ley No 18.575 (23/12/1986), Orgánica Constitucional de bases generales de la administración del Estado.

LeY No 19.880 (29/5/2003), establece bases de los procedimientos administrativos que rigen los actos de los órganos de la administración del Estado.

LeY No 19.886 (30/7/2003), de bases sobre contratos administrativos de suministro y prestación de servicios.

Decreto No 250 (24/9/2004), Ministerio de Hacienda, aprueba reglamento de la Ley No 19.886 de bases sobre contratos administrativos de suministro y prestaciones de servicios.

\section{JURISPRUDENCIA CITADA}

\section{Corte Suprema}

Cas Chile S.A. con Municipalidad de la Pintana: Corte Suprema, 25 de julio de 2019 (casación de fondo), Rol No 11.527-2019.

Espacio y Jardín LtdDa. con Ilustre Municipalidad de IQuiQue: Corte Suprema, 21 de diciembre de 2017 (casación en forma y fondo), Rol No 4001-2017.

Grisoifa y Compañía Limitada con CENTRAL de Abastecimiento del Sistema Nacional del SERVICIO DE SALUD: Corte Suprema, 22 de marzo de 2013 (casación en forma y fondo), Rol No 6988-2012.

SALUD Y VIDA S.A Y OtRos. con Junta NACIONAL DE Auxilio Escolar y BECAS: Corte Suprema, 4 de julio de 2017 (apelación amparo económico), Rol No 6080-2017.

SEguridad Integral TMI S.A. con Hospital Barros Luco: Corte Suprema, 17 de diciembre de 2015 (queja), Rol No 7460-2015.

\section{Contraloría General de la República}

DiCTAMEN CGR No 31.616, 24 de noviembre de 1989.

Dictamen CGR No 48.732, 9 de agosto de 2012.

DiCTAMEN CGR No 4.508, 22 de enero de 2013.

DiCTAMEN CGR No 34.523, 4 de junio de 2013.

DiCTAMEN CGR No 47.611, 26 de julio de 2013.

DiCTAMEN CGR No 30.003, 29 de abril de 2014.

Dictamen CGR No 16.307, 11 de abril de 2018.

Dictamen CGR No 11.961, 10 de mayo de 2018. 